\title{
Active, experiential and reflective training in Civil Engineering: Evaluation of a Project-Based Learning Proposal
}

\section{by}

Authors: Marina Miranda(1) $\left({ }^{*}\right)$, Ángela Saiz-Linares(2), Almudena da Costa(3) and Jorge Castro(4)

(1) (3) (4) Group of Geotechnical Engineering, Department of Ground Engineering and Materials Science, University of Cantabria. Avda. de Los Castros, s/n 39005 Santander, Spain. Tel.: +34 942 201813

(2) Didactics and School Organization, Department of Education, University of Cantabria. Avda. de Los Castros, s/n 39005 Santander, Spain. Tel.: +34 942201883

e-mail: mirandama@unican.es $\left({ }^{1}\right)$; angela.saizl@unican.es $\left({ }^{2}\right)$ dacostaa@unican.es; $\left({ }^{3}\right)$ castrogj@unican.es ( $\left.{ }^{4}\right)$

$\left.{ }^{*}\right)$ Corresponding author

Words: 11211 


\title{
Active, experiential and reflective training in Civil Engineering: Evaluation of a Project-Based Learning Proposal.
}

\begin{abstract}
In today's industry, employers are looking for civil engineering graduates who have acquired not only substantial technical and scientific knowledge, but who also have good life-long learning skills such as problem solving, creativity and communication skills. Therefore, it is necessary to leave behind the pedagogical approaches exclusively sustained in masterclasses in favour of active, experiential and reflective curricula. Thus, a Project-Based Learning (PjBL) strategy has been developed as part of two geotechnical courses within a civil engineering degree in Spain to promote these skills. A qualitative analysis of the implemented PjBL strategy is performed by means of questionnaires and interviews with the aim of considering the participants' perceptions. The results of the analysis are presented under the following headings: benefits and difficulties of the PjBL, teacher role, traditional teaching methods and measures of improvement. The results suggest a satisfactory implementation, and they have allowed the authors to share the lessons learned from this experience by generating some "tips" for future implementations.
\end{abstract}

Keywords: project based learning, teamwork, active learning, lifelong learning skills, reflective training, and engineering education.

\section{INTRODUCTION}

Nowadays, industry stakeholders require graduates to have substantial technical and scientific knowledge together with social skills and good problem-solving abilities (Lang et al., 1999). Among these abilities, teamwork, problem solving, decision-making and communication skills in combination with practical experience are the ones which are most in demand and least commonly found in today's civil engineering graduates (Mills and Treagust, 2003). Traditional teaching methods still dominate engineering teaching practice, the main delivery mode being lecture-based. This methodology by itself has been proved to be ineffective (Mills and Treagust, 2003). It is mainly a passive approach that promotes surface learning, with the emphasis on memorizing facts rather than on identifying the underlying patterns (Brockbank and McGill, 1998; Brohn and Cowan 1977). Cosgrove and O'Reilly (2019) pointed out that under this type 
of training, some graduates, when dealing with a real world problem, may show procedural expertise with little understanding of how the concepts and principles at play in these procedures relate to each other. This might be due, among other factors, to the lack of a significant problem context of which to make sense and to integrate the disciplinary knowledge (Cosgrove and O'Reilly, 2019). In addition, it usually leaves behind the reflective part of the scientific process because the action-reflection-action cycle is not present. It is precisely that cycle that results in knowledge creation and which is linked to theory building and/or theory testing (Greenwood and Levin 2007). Thus, changes should be implemented in the current engineering curriculum design and teaching practice to promote deeper understandings, to enable critical interactions with the teaching contents, to make connections and to draw conclusions (Brockbank and McGill, 1998).

Several approaches have been proposed to overcome the previously presented shortcomings and to follow the principles of the Bologna declaration by developing students' competences. Most procedures require a shift to student-centred teaching strategies and active learning environments, leaving behind the teacher-centred approach associated with traditional teaching practices ("chalk and talk"), where passive learning is promoted. These principles advocated by Bolonga are aligned with the pedagogical proposals of reflective models (Beavers et al. 2017; Wong, 2016; Bruno and Dell'Aversana, 2018). The reflective practice movement is concerned with professional education curricula that recognise and develop the richness of practitioners' experiences and their ability to take substantive decisions on the means and purposes of their work (Schön, 1987). In this regard, reflection is a process of transforming experience into learning (Bruno and Dell'Aversana 2018) and making practical knowledge the main focus of reflection (Schön, 1983; 1987). The creative struggle stimulated by practical design situations, or the "undetermined zones of practice" (Schön, 1983), are triggers of the reflective processes

Reflection applies to relatively complicated, confusing and complex ideas and situations for which there is no obvious solution. The solution is primarily based on processing and understanding the knowledge we already own. (Moon, 2007, p. 192).

The heart of reflective processes can be found in our efforts to understand this situation and, lastly, in the process of restructuring the problem or this conflicting area of practice (Loughran 2002; Russell, 2018; Thompson y Pascal, 2012). In these cases, action and experimentation act as triggers of reflexive processes. Similarly, the experiential learning cycle proposed by Kolb (1984) states that learning is the result of a process that begins with the observation and reflective analysis of a concrete experience as a means to formulate a theory that is 
implemented back into practice again with the action. Along similar lines, Boud et al. (2013) relate experiential learning with reflection. They present a reflection that takes place in various stages: first, the anticipation of the experience and next, during the experience as a way of dealing with the large number of inputs and responding to the feelings that have been generated. Finally, reflection after the experience helps to order and give meaning to the new ideas and information that have been produced. These reflective phases coincide with those described by Schön $(1983 ; 1987)$ that still prevail. They are: i) reflection-in-action, which occurs while the action takes place, and ii) reflection-on-action, a type of reflection that takes place once the action has concluded. This last phase of reflection serves to re-examine the most basic assumptions, but also to develop deeper insights that can then be applied to the original situation or to other similar ones. Nonetheless, reflective practice cannot be understood exclusively as an individual action. If so, there is the risk of turning learning into a selfconfirmatory process that helps to validate our internal thinking (Brookfield, 1998; Fendler, 2003). Therefore, developing reflective experiences in a collaborative atmosphere is vital for understanding other points of view and for questioning practices (Zeichner, 2010).

These considerations on reflective practice have helped teachers to rethink university education, emphasizing the need to drop decontextualized training approaches in favour of training proposals responding to real and complex professional situations. This active and reflective learning approach is, in fact, a priority in the restructuring process of the European Higher Education Area. Considering that people learn through experience, as described by Russell (2018), 'learning from personal experience tends to be more powerful and lasting than observing or being told about it' (p. 6), it makes sense to promote the resolution of practical problems in engineering training. In this way, university curricula should include a reflective element and be based on situations and projects similar to the ones found in professional practice (Schön, 1983). In this context, it is worth noting that most of the tasks in engineering professional practice are in relation to projects. Their time, scale and complexity are variable and can involve just one or more areas of specialization. Thus, considering all the above, one suitable approach for developing reflective practice in engineering is to introduce Project-Based Learning (PjBL) strategies, as already analyzed by other authors such as Brodie (2007), Cosgrove and O'Reilly (2019), Cosgrove et al. (2014), Gavin, (2012), Sonntag, (2006) and Turns et al. (2014). PjBL proposals encourage students to reflect on and learn from educational experiences based on real-life professional practice situations. The essence of the learning process are the continuous cycles of planning, action and reflection carried out in collaboration (among students and with the teacher) (Cosgrove and O'Reilly, 2019). 
A simple definition of PjBL is the one given by Thomas (2000) "it is a model that organizes learning around projects". De Camargo Ribeiroa (2008) nuanced the definition by saying that the projects are representative of real-life situations. Du and Kolmos, (2009) define PjBL as a new learning philosophy where active learning is the centre. Therefore, the students are active in the process of turning information into knowledge (Mills and Treagust, 2003; Perrenet et al., 2000). However, it is worth mentioning that 'students learn by doing, but only when they have time to reflect' (Ambrose, 2013, p. 1). Therefore, in PjBL proposals, action and experimentation are as important as the reflective work. In fact, the learning process takes place only when students reflect on the experience by analyzing the situation provided and evaluating the decisions made. This might guide future actions and future experiences (Cosgrove and O'Reilly, 2019; Turns et al., 2014).

Sometimes project-based learning and problem-based learning are interchangeable. Both learning strategies are similar as they are based on collaboration and self-direction, but the former is more directed to the application of knowledge and the latter is more oriented towards knowledge acquisition (Lantada et al., 2013). In addition, PjBL tasks are closer to real professional activities, they are more focused on applying knowledge and usually, time management is an important factor. Furthermore, $\mathrm{PjBL}$ is commonly complemented with subject courses, which is important for acquiring engineering knowledge as its nature is sequential and includes fundamental scientific and technical knowledge (Mills and Treagust, 2003). Yadav et al. (2011) emphasize that PjBL activities in engineering are usually focused on the final product and formal instructions previously given to students, so they have a certain previous level of knowledge. In practice, the degree of teacher guidance to students in relation with the proposed objectives varies in each case (Graaff and Kolmos, 2003). Based on implemented PjBL strategies, Kokotsaki et al. (2016) presented several recommendations focused on teacher support of students and on balancing autonomous work and guidance to promote reflection. Likewise, there are several methodologies for designing PjBL strategies and activities (Graeber, 2012; Jonassen, 1997; Nelson, 1999). García-Martín and Pérez-Martínez (2017) provided a detailed guidance for developing PjBL activities divided in three phases: definition, support and organization. However, there are cases where teachers tend to implement PjBL intuitively, based on their teaching experience, rather than following the fundamentals and principles that guide PjBL proposals (García-Martín and Pérez-Martínez, 2017).

PjBL has been applied to science teaching practice since the 1970s (Illeris, 1976; Schmidt,1983) and it has been in development since then, also being implemented in engineering education 
(Du and Kolmos, 2009; Kolmos and Rasmussen, 1994). However, it was not until recently that the international engineering education community has decided to share experiences and knowledge about these practices in webinars (Guerra et al., 2017) with the aim of providing inspiration and promoting this methodology. One of the barriers for PjBL implementation is the difficulty of assessing the success of $\mathrm{PJBL}$ implementation when comparing it to traditional teaching methods (Heitmann, 1996). Graham and Crawley (2010) identified student recruitment and retention as one of the main drivers of PjBL implementation, together with the call of industrial stakeholders to equip graduates with a broader set of skills (Graham and Crawley, 2010). Nowadays PjBL has been proved to be effective in developing the required engineering graduates' skills (Heitmann, 1996). Aalborg University of Denmark's project-based engineering program is the most well-known example of a PjBL-based curriculum (Kolmos,1996) and it is one proof of the effectiveness of this strategy. Other successful experiences of PjBL have been implemented in Central Queensland University in Australia for courses of civil engineering (Wolfs et al., 1998), in individual courses in different engineering degrees in the UK (Graham and Crawley, 2010) and in the USA (Starcher and Pierce, 2016; Larson et al., 2018). In Aveiro, Portugal, following an initial implementation on one undergraduate course (Pinho-Lopes and Macedo, 2016), a PjBL activity based on engineering software packages has been successfully implemented in a Geotechnical engineering course on a Master degree (Macedo and PinhoLopes, 2018). These examples show the positive performance of the PjBL methodology and underline the current popularity of PjBL strategy in engineering education (Guerra et al., 2017). In most cases, a further development of students' teamwork abilities, communication skills, managerial skills, decision-making and application of knowledge to real life situations have been achieved. These findings make sense because as Cosgrove et al. (2010) state, "attitudes and habits are not formed by transmitting content, but by embedding work with appropriate content within an effective process" (p. 2). In addition, several information networks have been created to share best practices and the experience acquired between engineering academics (Christie and de Graaff, 2017; Graham and Crawley, 2010).

However, there are also several PjBL implementations that have not been so successful, such as the one developed in Australia since 2015 presented by Gratchev and Jeng (2018). They showed that students were reluctant to adapt to the change in the learning and teaching strategy. This was also found by Pinho-Lopes and Macedo (2016) at the beginning. They identified the increase in workload for students as the potential cause.

Despite all this, experience in PjBL application in engineering courses in Spain is limited (GarcíaMartín and Pérez-Martínez, 2017). There are just a few examples (Lantada et al., 2013; Macías 
et al., 2005; Pérez et al., 2011) and most of them are performed only within an individual course and not for the whole degree curriculum. This proves that the PjBL strategy is not yet consolidated in Spanish engineering courses. This lack of development might be due to the limitations of faculty time, faculty experience, facilitator training, resources, learning spaces and accreditation concerns, which are some of the barriers to PjBL implementation (Graham and Crawley, 2010).

Considering the current popularity of the PjBL strategy and the lack of examples in engineering courses and curriculums in Spain, a new educational proposal was developed in a Spanish engineering degree, namely in the Civil Engineering undergraduate program of the University of Cantabria (Spain). The previous experience of the teacher at Edinburgh Napier University, where a more experiential and student-centred educational strategy was applied, is the origin of this training proposal. It was implemented with the aim of promoting active and reflective learning plus collaborative and practical strategies where students would become "researchers" in a practical context shaped by continuous decision-making (Schön, 1987). This paper acknowledges, describes, analyzes and improves the design of this proposal. All this with the purpose of presenting some key ideas that might inspire other Spanish engineering faculties that want to promote the development of collaborative, reflective and experimental training strategies, through a PjBL approach.

\section{PjBL proposal description and context}

The PjBL proposal was implemented in the Civil Engineering degree at the University of Cantabria (UC). It was developed in two modules. Firstly, it was incorporated in a module of the fourth year (last year). This is the second course related with geotechnical engineering, named Geotechnical Works. It is a compulsory course for the students undertaking the branch of Civil Constructions and it is taught in English. In this case study, the PjBL proposal was implemented as part of the teaching-learning strategy. It was complemented with more directed lectures and tutorials to ensure the knowledge of scientific, technical and engineering fundamentals (Mills and Treagust, 2003). A total of 30 students were involved. After this first experience, the PjBL proposal was also implemented in an equivalent module (Geotechnical Engineering: Foundations, excavations and tunnels) which pertain to the Cornell Program of the School. This program combines students from the University of Cantabria and Cornell University. This module has the same contents as the one presented above but it is taught in second year. In this module, 11 students took part in the PjBL proposal that was slightly modified based on the experience and analysis of the first implementation. 
The PjBL proposal is in the topic of 'Deep Foundations'. The final objective is to design in groups a small-scale deep foundation, which is built by means of a 3D printer. Once the prototype is built, it is tested in the laboratory to observe its behavior and the effectiveness of the designs. A $22 \mathrm{~cm}$ layer of dry clean sand is the soil layer into which the piles will be driven. In each case, it is placed in a box to achieve the required density as each group is given a specific density and a design load, e..g. ( $\gamma=14.5 \mathrm{kN} / \mathrm{m}^{3}$ and $\left.\mathrm{L}=100 \mathrm{~N}\right)$. The students are given the particle size distribution of the sand, its maximum and minimum dry unit weight and a series of shear box test results for samples at the loose, medium and dense state of the sand. From the data provided, each group should obtain the strength parameters they need to design the piles and perform the calculations to come up with the design. Once the pile group design is finalized, it is printed and driven into the sand. This allows students to see their design and to have a more accurate impression of its proportions and dimensions. All the piles are driven at the same time in the sand and even if it does not replicate the real procedure, it still shows the disturbance of the surrounding soil. Once they are installed, the load is applied and students are able to see the displacement generated, the maximum load capacity and the point of failure of their design. More details can be found in Miranda et al. (2019).

Students worked in small groups of 4 or 5 people in the first implementation and 3 or 4 in the second to solve this open-ended problem guided by the instructors. The whole PjBL proposal was developed for 8 weeks, around $40 \%$ of the duration of the module. Total student work time was around $30 \mathrm{~h}$. Table 1 presents a summary of the time distribution during the project, divided in: face-to-face time, moderated meetings, practical lab and self-study. It also shows that the project's approach is based on the four phases required to develop a reflective practice, proposed by Cosgrove et al. (2014):

- Triggering event or indeterminate zones of practice

- Exploration (discussion about the nature of the problem)

- Integration (connecting ideas and applying various theories to the problem)

- Resolution (applying new ideas to solve the problem)

Table 1. Timeline and students' work hours of the project

\begin{tabular}{|c|c|c|c|c|c|c|}
\hline & & \multirow{2}{*}{\multicolumn{5}{|c|}{ hours }} \\
\hline & & & & & \\
\hline $\begin{array}{l}\text { Phases of } \\
\text { reflective } \\
\text { practice } \\
\text { (Cosgrove et } \\
\text { al., 2014) }\end{array}$ & timeline & lecture & $\begin{array}{l}\text { self- } \\
\text { study }\end{array}$ & $\begin{array}{l}\text { moderated } \\
\text { meetings }\end{array}$ & practical lab & $\begin{array}{c}\text { total } \\
\text { student } \\
\text { work } \\
\text { hours }\end{array}$ \\
\hline
\end{tabular}




\begin{tabular}{|c|c|c|c|c|c|c|}
\hline $\begin{array}{c}\text { Triggering } \\
\text { event }\end{array}$ & $\begin{array}{l}\text { 1st week } \\
\text { Presentatio } \\
\mathrm{n}\end{array}$ & $\begin{array}{l}4 \text { project } \\
\text { presentation } \\
\text { pile design } \\
\text { principles }\end{array}$ & 6 & $\begin{array}{l}1 \text { guidance } \\
\text { about soil } \\
\text { parameters }\end{array}$ & & 11 \\
\hline \multirow{2}{*}{ Exploration } & $\begin{array}{l}\text { 2nd week } \\
\text { design } \\
\text { options }\end{array}$ & & 4 & $\begin{array}{c}1 \text { guidance } \\
\text { about design } \\
\text { options }\end{array}$ & & 5 \\
\hline & $\begin{array}{l}\text { 3rd week } \\
\text { First design }\end{array}$ & & 2 & $\begin{array}{c}1 \text { feedback } \\
\text { about first } \\
\text { design }\end{array}$ & & 3 \\
\hline \multirow{3}{*}{ Integration } & $\begin{array}{l}\text { 4th week } \\
\text { Final design }\end{array}$ & & 2 & $\begin{array}{c}1 \text { feedback } \\
\text { about final } \\
\text { design }\end{array}$ & & 3 \\
\hline & $\begin{array}{l}\text { 5th week } \\
\text { Printing } \\
\text { prototypes }\end{array}$ & & 1 & & $\begin{array}{c}1 \text { print } \\
\text { prototypes }\end{array}$ & 2 \\
\hline & $\begin{array}{l}\text { 6th week } \\
\text { Laboratory } \\
\text { testing }\end{array}$ & & 1 & $\begin{array}{l}1 \text { feedback } \\
\text { about } \\
\text { experimental } \\
\text { results }\end{array}$ & $\begin{array}{c}2 \\
\text { preparation } \\
\text { of soil and } \\
\text { testing } \\
\end{array}$ & 4 \\
\hline \multirow[t]{2}{*}{ Resolution } & $\begin{array}{l}\text { 7th week } \\
\text { Discussion } \\
\text { session }\end{array}$ & 2 pile design & 1 & $\begin{array}{l}1 \text { comparison } \\
\text { between } \\
\text { experimental } \\
\text { and analytical } \\
\text { results }\end{array}$ & & 4 \\
\hline & $\begin{array}{l}\text { 8th week } \\
\text { Portfolio } \\
\text { submission }\end{array}$ & & 1 & 1 & & 2 \\
\hline
\end{tabular}

The design of the PjBL followed the guidelines provided by García-Martín and Pérez-Martínez (2017). This helped to divide the project in phases and to set the submissions according to the knowledge and skills that were to be promoted, as presented in Table 2. In addition, weaker areas were previously identified so that more guidance could be provided in those moments. E.g. Students were pointed to some literature to help them during the first steps of the project; a second moderated meeting was provided between first and final design submissions.

Table 2. Structure of the implemented proposal

\begin{tabular}{|c|c|c|c|}
\hline Phases & Deliveries & $\begin{array}{c}\text { Technical } \\
\text { Knowledge }\end{array}$ & Life-long learning skills \\
\hline
\end{tabular}




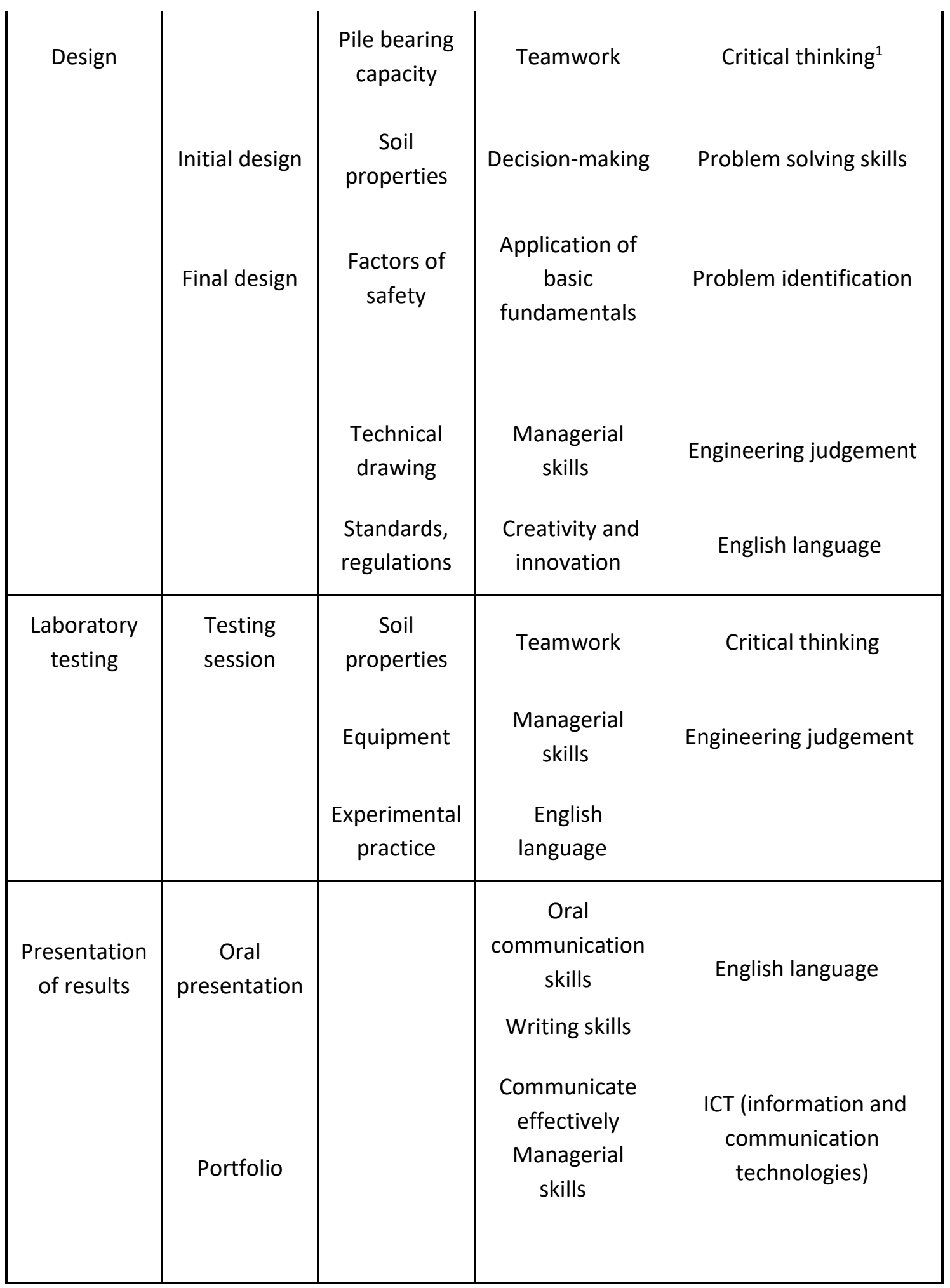

${ }^{1}$ Critical thinking defined as "the ability to perform a task, to reflect and question and to ground abstraction and reflection in the reality" (Facione, 2011). In this sense, it implies abilities such as problem solving, creative thinking and in the last instance, it also implies "to take the empirical and rise above this with abstraction and theory" (Ahern et al., 2012, p. 128). 
1) The initial phase is the one focused on the design and it has two submissions. Integration of previous knowledge, teamwork, decision-making and the acquisition and application of technical knowledge are the key abilities that need to be developed.

2) The second part is the experimental testing. The designed prototypes are printed (Figure 1a) and they are tested as shown in Figure $1 \mathrm{~b}$. This phase required more guidance, so the teacher was present during the whole process. The main objectives were development of engineering judgement, critical thinking and acquiring practical experience related with the use of equipment, working as part of a team and identifying problems encountered for future designs tasks.

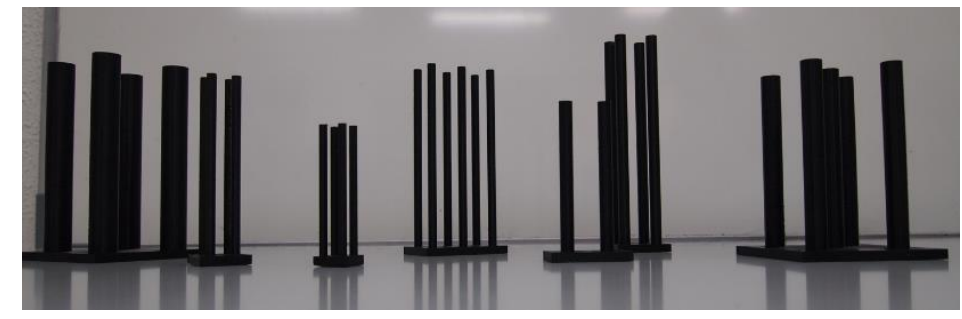

a)

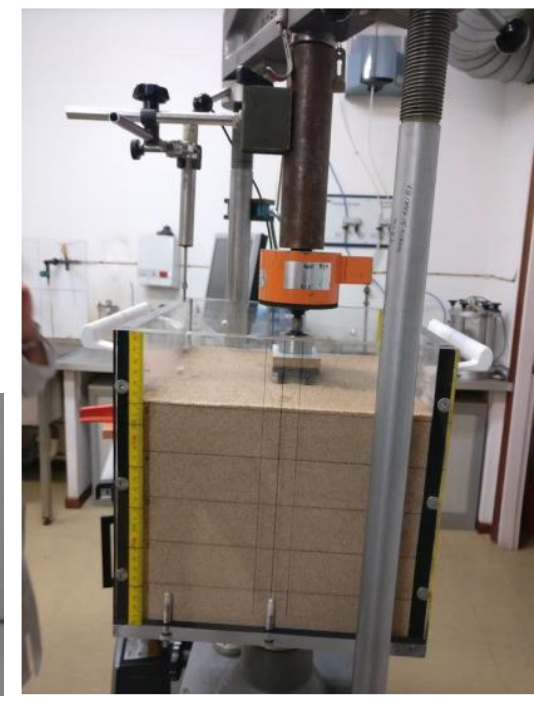

b)

Figure 1. a) Designed prototypes b) Set up of one prototype load-displacement testing

3) The last phase is the presentation of the results. This promotes the development of communication skills, both oral and written. As the whole project was done in English, it also furthers the students' acquisition and improvement of English as a foreign language. It is worth mentioning that the use of new technologies was also promoted as they used different graphic software, and everything was presented via Moodle.

An analysis of the first implementation was undertaken with the intention of identifying weak points in the first implementation of the PjBI curriculum and improving it in the future. The main modifications for the second implementation were to generate a general forum and a wiki (i.e. virtual publication collaborative edited by its members. In this case used as portfolio for each group with the aim of promoting collaborative work among peers and making teamwork easier). These improvements were developed for the second implementation. The wiki for each group was intended to promote a virtual space for managing teamwork and promoting collaborative learning among the group members. The forum was created with the idea of sharing knowledge 
and practice among the whole cohort. In other words, to promote collaborative learning with their peers and to generate guided discussions.

\section{Methodology}

The research conducted corresponds to an evaluative case study of a qualitative nature (Denzin and Lincoln, 2013; Flick, 2014; Simons, 2011). The adoption of this perspective makes it possible to examine the underlying meaning of the educational initiative, giving priority to the exegesis of the participants (Rapley, 2014). In other words, using a qualitative methodology approach may help us to reveal participants' perceptions, thoughts and feelings about the PjBL experience. It may also allow participants to communicate the educational value they see in the experience. Moreover, the design of a qualitative research is flexible and has a higher potential to adapt to the application context (Bisquerra and Sabariego, 2004).

This case is about a circular and emergent design. It has allowed reflection, continued revision and reconstruction on the steps and decisions taken throughout the process (Flick, 2014). Precisely, a first evaluation of the proposal at the end of the first four-month period has made it possible to develop some modifications that improve its implementation in the second fourmonth period.

This first evaluation was made by open-ended and closed questionnaires at the beginning and at the end of the project. Closed questionnaires included 12 questions and it was inspired by the one proposed by Silva et al. (2012). Several questions of the initial open-ended and final closedended questionnaires can be found in Table 3.

\section{Table 3. Sample of questionnaire}

\begin{tabular}{|c|c|c|c|c|c|c|}
\hline Closed ended questionnaire & 1 & 2 & 3 & 4 & 5 & $\mathrm{x}$ \\
\hline 1. Was the aim of the project clear? & & & & & & \\
\hline 4. Did project development contribute to your learning? & & & & & & \\
\hline 5. Was previous knowledge sufficient for project development? & & & & & & \\
\hline 6. Was class development compatible with project development? & & & & & & \\
\hline 7. Was attendance to feedback sessions important for project development? & & & & & & \\
\hline 11. How do you rate the overall project development? & & & & & & \\
\hline \multicolumn{7}{|l|}{ open ended questionnaire } \\
\hline \multicolumn{7}{|l|}{ Do you think this activity will help you in your learning process? } \\
\hline \multicolumn{7}{|c|}{ Do you find it interesting that the activity is part of the course evaluation? Justify your answer } \\
\hline In your opinion, is working in groups suitable for this activity? Justify your answer & & & & & & \\
\hline
\end{tabular}


As pointed out before, this PjBL experience is developed at the University of Cantabria, specifically, in the School of Civil Engineering. It is at a nascent moment as only two modules have incorporated the PjBL proposal in their curriculum. Hence, the participants of these subjects (students and teachers) constitute our sample.

This study has tried to document participants' opinions, to integrate them into the process and to represent their different interests and values. Therefore, qualitative methods have been used for this purpose. Open-ended and closed-ended questionnaires ${ }^{2}$, semi-structured interviews and the analysis of the projects developed by each group have been the data collection strategies employed. Open-ended questionnaires were provided to the students of the two modules involved (30 students in the first semester and 11 in the second) at the beginning and at the end of the proposal. A semi-structured evaluation interview was conducted with five students individually after the proposal was completed. One interview was also conducted with the teacher of both subjects, in order to delve further into some relevant issues outlined more briefly in the questionnaires.

A script with a series of topics and questions was elaborated to articulate the conversation during the interviews. Nonetheless, it was conceived as an open format, so other equally relevant questions, that were not formerly contemplated, could emerge. This promotes the development of a conversational flow attached to the emotions, experiences and knowledge of the interviewees (Fontana and Frey, 2005; Kvale, 2011). Two researchers with knowledge of the subject (experts), from the University of Cantabria, took part in its preparation. The definitive scripts resulted from a process of shared reflection that guarantees the validity of the instrument.

In the process of data production through interviews, it is important to highlight that some ethical considerations have been adopted (British Educational Research Association, 2003). The use of interviewing implies a process of dialogical interaction, which should be presided over by communication ethics. This implies recognizing all participants as authorized interlocutors with the right of reply and argumentation. Moreover, subjects have participated voluntarily in the research after having understood the intentions and implications of the study. This has been ensured by informed consents. In addition, confidentiality, anonymity and privacy protection were guaranteed (Grinyer, 2009). The interviewer, meanwhile, was a teacher from the Faculty of Education who had no role in the project implementation and was not involved in the

\footnotetext{
${ }^{2}$ Questionnaires had one part formed by closed-ended questions, type Likert, and another with openended questions.
} 
evaluation of the students. She was collaborating on the interviews to avoid conflicts regarding the position of power of the other teachers (who implemented and evaluated the proposal), as that could presumably affect the honesty of the interviewees' answers.

Once the data collection was completed, the information was recorded and subsequently transcribed. A thematic coding system, where codes and categories of analysis are defined, was used to analyze the data (Huber, 2003). Inductive and deductive strategies were employed, and one initial scheme of variables was established. However, the work undertaken on the data made it necessary to redefine some of these categories and codes during the analysis process. The development of theories was performed through an abstraction process (Flick, 2014). This coding allows a general evaluation of the proposal in its different phases. Finally, to manage the information and facilitate data reduction, the software MAXQDA (Kuckartz, 2007) has been used. The five categories resulting from this analysis process are presented in Table 4.

Table 4.. Categories for study

\begin{tabular}{ll}
\hline Categories & Definition \\
\hline $\begin{array}{l}\text { Traditional } \\
\text { teaching } \\
\text { methods }\end{array}$ & $\begin{array}{l}\text { Participants reflections and statements } \\
\text { about traditional teaching experiences } \\
\text { through their university education. }\end{array}$ \\
PjBL & $\begin{array}{l}\text { Information and reflections on the } \\
\text { advantages and benefits of the PjBL over } \\
\text { other types of education and on the learning } \\
\text { developed during the training proposal. }\end{array}$ \\
& $\begin{array}{l}\text { Observations and assessments about the } \\
\text { barriers or obstacles that the development of } \\
\text { the PjBL has led to. } \\
\text { difficulties }\end{array}$ \\
Teacher role & $\begin{array}{l}\text { Statements and reflections on the role of the } \\
\text { teacher (functions and activities) in the } \\
\text { design and implementation of the PjBL. }\end{array}$ \\
& $\begin{array}{l}\text { Information and reflections on issues that } \\
\text { could be improved in the design and } \\
\text { implementation of the PjBL in future } \\
\text { proposals. }\end{array}$
\end{tabular}




\section{Results and discussion}

\subsection{Traditional teaching approach in Civil Engineering}

All participants agreed that the main teaching strategy in Civil Engineering is based on lectures or masterclasses. This strategy is more focused on teaching theoretical knowledge than promoting experimental experiences applied to professional life practices.

We focus a lot on theory and following some guidelines for doing the exercises and sometimes we get the feeling that we don't know very well what the exercises are for. (Interview_student1)

In this sense, students point out that there are few opportunities to address practical situations related to real-world practices. Moreover, sometimes this more applied learning is expected to be produced in a vicarious way from the observation of a teacher who manipulates the laboratory equipment. These shortcomings might be explained by the fact that the teaching staff prefer to remain within their 'comfort zone' and by the high price of materials.

Normally the practical sessions that we do consist of going to the laboratory and watching how the teachers do the practices. They don't usually let us touch anything. I don't know, I understand that they will be expensive machines... (Interview_student3)

Consequently, the students' role is relegated to a receptive and passive one, where they have very few opportunities to take on challenges that imply a certain autonomy to make decisions. Thus, the type of activities and exercises proposed are closed and highly structured, so that the configuration of learning based on reflection and inquiring into real situations and problems of professional practice does not often take place.

Normal exercises are like following a procedure all the time and that doesn't give you much room to think because it is always the same thing. (Interview_student2)

Participants also reveal that teaching tends to be organized individually, with few possibilities for students to collaborate and network.

[They do not usually work in groups] For us it is easier to evaluate individually each student. Managing groups is already a problem... I think it is because of convenience... (Interview_teacher)

In summary, the syllabus has a strong academic orientation and it is essentially organized around basic science to the detriment of an active and experiential training linked to the applications of the professional world, as also happens in many others Engineering Schools (Schön, 1987). Although this is the dominant focus, $100 \%$ of the participants highlight, in the interviews and 
questionnaires, the need to include training initiatives with a strong experiential component such as the one they have experienced.

We need more experiences like this, and I would like M. [subject teacher] to talk to other teachers and encourage them to do so in other subjects... Because we are more comfortable when they give us the guidelines and it shouldn't be like that. Especially for us who are going to be engineers and in the professional future we are not going to have them. (Interview_student1)

\subsection{PjBL benefits versus traditional teaching methods}

\subsubsection{Active, reflective and experimental learning}

As presented above, this initiative was based on the previous experience of one of the teachers in Edinburgh Napier University. She herself participated in a PjBL experience and saw how this type of initiative raised students' motivation and involvement. In addition, it promotes types of learning not normally encountered in traditional "chalk-and-talk" methods.

I had done a similar activity at the University where I had previously worked in Edinburgh and $\mathrm{I}$ had seen that it motivated the students a lot. (Interview_teacher)

In the implementation of the PjBL proposal in Cantabria (Spain), the benefits for student learning and professional development are also tangible. They are detailed below.

Firstly, this teaching approach makes it possible to develop active and experiential learning, based on real situations of professional practice.

I think doing exercises in class makes sense because you repeat things, but this made me understand how the design changes if the friction angle changes... oh! That actually changes that.... If something else is changed, it actually changes the other thing. I think I have a better understanding of pile design because of this project. You could get to see what your design is like in the real world. (Interview_student4)

The PjBL proposal allows students to understand the complexity and multifactorial nature of professional practice. This is in line with the findings presented by Chinowsky et al. (2006), who show in their study that all the students interviewed agreed that they gained a deeper understanding of working in the real industry.

In this experience, students are confronted with problematic situations of practice. Hence students are required to put theory into practice, reflect, make decisions and try ad hoc strategies, as would happen in a real work situation. In other words, PjBL favours the ability to form questions that extend beyond the normal boundaries of an assignment, as stated by Chinowsky et al. (2006). It also acts as a vehicle to encourage higher order critical and creative thinking in students, as described by McCrum (2017). 
We give them the soil type and some test results, as they would give you in reality, we don't give them directly the soil parameters, but we give them the tests as they would be given to you in a project office. Then they have to obtain the parameters of the soil. So that part is quite complicated for them, to make those decisions, until now... Well, usually it is: you've got this and calculate this. They do not have to choose. So here, they can think about it, they can vary... (Interview teacher)

It helped me consider aspects of pile design that are important in real life (cost per Project, overdesigning, etc.). Things like these, I believe, can't be taught. One needs to learn about it in real life. (Final questionnaire)

Precisely, taking as a starting point the "indeterminate zones of practice" (Schön, 1987) enables the participants to trigger reflective processes that ultimately favour significant and lasting learning (Russell, 2018; Thompson and Pascal, 2012). Students' theoretical and general knowledge questioned in the face of a dilemma can be consolidated and linked to real practice. This principle is endorsed by the work of de los Ríos et al. (2010), who after 20years of experience with project-based learning in agronomy, conclude that $\mathrm{PjBL}$ is the most adequate educational methodology for the development of competences that enable teaching to be linked with the professional sphere.

On the other hand, in the PjBL approach there is usually no single valid way to solve the problem. Hence, students must develop their creativity and innovative capacity, which are fundamental skills for engineering students (Nordstrom and Korpelainen, 2011).

I felt it was helpful just in terms of like... I feel like doing something hands on kind of having like a lab aspect of the class. Just because then... Then you can see and are able to apply some of the methods that we were using in class and see... (Interview_student5)

The analysis of the projects developed by each group of students reveals that generally the designs presented were technically sound as they presented backup calculations and explanations. They show a good application of new and previous knowledge. From this, it can be deduced that a deep understanding of the bearing capacity of piles has been developed in agreement with student perception.

In short, it is in this process of building one's own procedures to solve a problematic situation, where the real learning resides. This will allow the professional to "learn to learn" throughout life and become a more skilful practitioner.

To conclude this section, it should be noted that it is not intended that this PjBL approach should replace academic learning with experiential learning. Theoretical training is undoubtedly necessary, but as the teacher emphasizes, it must be complemented and coordinated with a practical training. This is one of the main conclusions presented by Hosseinzadeh and 
Hesamzadeh (2013), who pointed out that having traditional lecture-based courses was helpful in laying the required knowledge foundation for more advanced courses, which could be delivered in PjBL. This complementation allows the student not to fragment the countless sources of knowledge, techniques, skills and decisions that a practicing professional combines and coordinates when facing the unique situations of his practice.

It's like a process similar to what they're going to do [in their profession]. But, of course, I think that if you just follow this methodology, it's a little complicated... like the technical knowledge itself being learned.... So, I think there has to be a mix, a balance. (Interview_teacher)

\subsubsection{Development of lifelong learning skills. Social abilities, teamwork, oral communication and managerial skills.}

University education cannot be solely devoted to technical education, leaving aside the conglomerate of skills that are fundamental to the performance of any professional. Teamwork skills, for example, are also important in engineering. Therefore, the implemented PjBL proposes a type of teaching and learning that is developed collaboratively. Students work mainly in groups, inside and outside the classroom, solving problems together and learning collaboratively.

Thus, this methodology has allowed students to discover their peers as a valuable source of knowledge and learning. It has also helped them to recognize the collaborative nature of professional engineering practice, supported by the common objectives pursued. According to the perceptions of the participants, teamwork allows them to consider points of view that, until now, had not been part of their thinking and processing schemes. As pointed out by Mills and Treagust (2003), PjBL allows competences in the evaluation of alternative views and the negotiation of understanding to be developed. In other words, it is a process of deconstruction of their own knowledge schemes and the construction of new frameworks that integrate a more complex and polyhedral vision of the proposed work situation.

Opinions of everybody. If someone else hadn't mentioned an idea, I wouldn't have known how to do it. Just see how other people think... (Interview_student2)

This is consistent with the literature related with $\mathrm{PjBL}$, since one of the main results is the development of skills related to work in teams and cooperative problem-solving which, moreover, increase students' motivation and engagement (Chandrasekaran et al., 2013; de los Ríos et al., 2010; Pinho and Macedo, 2016).

In addition, participants in the second semester (Cornell group) highlight the opportunity to collaborate with colleagues from other countries. This has made it possible to observe different ways of working. Instead of being an obstacle, it has become a fertile source of learning and 
exchange. On the other hand, both subjects have favoured the use of English as a vehicle for communication, which is a fundamental competence in today's labour market.

To work with different people, to see how they work, because in my group there were people from UC and also from USA and Norway, so in the end we all have ways of working a little different. So, see how you can mix everything together to come to a conclusion... (Interview_student3)

Finally, working in groups has made it possible to discover the strengths of each student, as well as to articulate their own ways of organizing and managing work according to these skills. In this sense, they have also had to manage small group conflicts and different levels of involvement of the members in the group. This cooperation to solve problems and the self-determination of the group in the task result in the development of managerial skills.

We have each contributed our bit and we have each of us been important in our way. We divided the work according to what we thought we could do better. (Interview_student4)

Consequently, interpersonal and communicative skills constitute one of the strong points of this initiative. This is aligned with the conclusions presented by Gavin (2011).

The challenges of undertaking oral presentations, reported by participants in this study support Gavin's conclusions. They continuously refer to the fear and nerves to talk in public. It is important to consider that the Project was developed in English, so speaking in a foreign language (most of the students were Spanish) is an additional difficulty. However, everyone also recognizes the need to promote this type of practice that is so necessary in the engineering profession and so scarce, paradoxically, in the university syllabus.

I just don't like presentations, talking in front of people. But I think presentation is very important because one can find the cure for cancer, but if you do not know how to present the results, not to show people what you did, you lose everything. (Interview_student2)

\subsection{Difficulties in PjBL development}

In this section, the barriers and/or negative aspects related to the design and development of the PjBL experience identified by the participants are presented.

The complexities linked to the curricular integration of the proposal are highlighted. They are especially pressing due to its novelty in the School of Civil Engineering, which has always followed a traditional instructional approach: not to forget the tendency of teachers to work in isolation, with scarce collaboration and support between them.

The launch was complicated because since it was the first time and it had to be managed with the teaching plan that existed before, it was necessary to change the temporal structure... there are many factors and all of them had not been 
taken into account. And then, managing the first group, which were 30 people... (Interview_teacher)

These difficulties have been recognized in other studies. De los Ríos et al. (2010) pointed out the qualitative leap that accompanies the change from methodologies based on the individual work of the professor to those based on more complex structures. For their part, Adriaenssens et al. (2015), Justo and Delgado (2015) and Pinho and Macedo (2016), highlight that it is more timeconsuming to prepare a project than to use the traditional approach.

At the same time, the teacher also observed a certain initial discomfort in the students when she presented the proposal to the group of the second term. She understands that they might experience the continuous assessment of the Bologna Plan as an overload of activities, which might explain this initial repudiation.

I think they have to do too many, as small examples or quizzes at the end of each class in all subjects, so they are a little overloaded with small activities, and then, at the beginning when this project was exposed, it was like: another thing more, a lot of time, I cannot do it. Then, as it has progressed, that attitude has improved: ah! well, it's different, this interests me. But at first, they were reluctant. (Interview_teacher)

The difficulties stemming from the absence of a rigid structure in the approach of the proposal are also relevant. They tend to generate an initial feeling of bewilderment in the students.

Difficult... maybe just at the beginning trying to figure it out where to start. Starting from scratch was more difficult that I have anticipated. Given the data, you are overwhelmed because it is a huge amount of data and you are trying to see what is important. The hardest part was starting that; once you have a clearer idea of where you want to go, then it is easier. (Interview_student4).

Students felt overwhelmed at the beginning because they needed to reflect on previous knowledge to make decisions and use their engineering judgement. However, this inaugural cognitive conflict is fundamental in unleashing the intended reflective activity and constructive learning. Furthermore, these initial adversities among students seem to be normal when PjBL strategies are first introduced as learning activities, as supported by several studies (Gratchev and Jeng, 2018; Mckenna et al., 2018).

On the other hand, both the students and the teacher acknowledge the failure of one of the proposed activities within the PjBL; the use of the wiki and the forum. They were developed with the idea of amplifying the reflective interaction between students about their projects in an asynchronous communication format, but they have not been effective. This lack of engagement with the wiki and forum may be explained by several factors: technical ignorance of its functioning and formative possibilities; the scarcity of time and the lack of instructions on their use and intention, among others. Finally, it is important to take into account that students have 
had a fruitful interaction in their encounters in the classroom. All this has rendered meaningless a parallel interaction in the technological field.

We haven't used the forum. Last year we used it for something, but we didn't use it very much. The truth is that when something needed to be discussed, we discussed it directly in class, so we didn't need to discuss it online either. (Interview_student2)

The development of the oral presentation of the project was also recurrently referred in the critical remarks of the participants. In the first place, the debate that followed each presentation was insufficient. There was little participation of the whole class, making the activity a one-way issue. Also, since the projects of each group were analogous, the students emphasize that the presentation session, as well as the laboratory testing session, became somewhat tedious and repetitive.

The final debate? In the end, 3 or 4 spoke because they feel comfortable in the language, second because in the end they are more confident... (Interview_teacher)

\subsection{The role of the teacher in PjBL strategies: from instructor to facilitator}

Any initiative of active and experiential training must rethink the pedagogical relations between teachers and students towards more symmetrical and interactive forms (Brockbank and McGill, 1998).

Well, my job was as a facilitator. The idea is that this time I couldn't guide the work or tell them what it is... well, I could tell them, if they had to find information where to look for it, but how to be a little... least direct as possible. Hence, they are the ones who have the initiative, just perhaps to redirect them. (Interview_teacher)

Her role was to answer our questions, but not to answer them straight away, but to guide us asking us things in a way that we would end up answering our own questions, which I believe, is the way to learn. (Interview_student3)

This fragment shows how the teacher has adopted a facilitating approach based on: clarification of doubts, clarification of the work scheme, return of some ideas to be rethought, the proposal of means and resources to help students to reorient their work, etc. In other words, her role lies in helping students navigate by themselves in the "indeterminate zones of practice" (Schön, 1987). In this sense, it moves away from the traditional position of the "expert" teacher, who governs the learning processes, giving students the correct answer that is usually accepted without question. Gavin (2011) showed that PjBL significantly enhances and increases teacherstudent interaction and hence it benefits relationships as a result of one to one meetings, smallgroup informal sessions and the new role assumed by the teacher. 


\subsection{Some proposals for improvement}

This section concludes with some proposals for improvement regarding the implementation of future PjBL projects in this educational context.

To start with, several participants describe the need to think of more internally consistent training plans: plans where initiatives of this scope are not limited to isolated subjects but embrace a more globalized and modular approach within the degree curriculum.

I'd like to make it more complicated, a little longer, because in the end it's been a project of days. I wish it could be applied to the whole subject during the whole term. I would like it to be longer, to encompass more. (Interview_student3)

The project took place for 8 weeks, although not all face-to-face hours were dedicated to the project (the basics for the design of flexible walls were introduced as well during those weeks). However, the PjBL activity required sufficient independent work by the students in groups outside the classroom. This might explain the student perception in relation with the time within the subject. Precisely, such a prescriptive curriculum as the present one makes it difficult to incorporate learning activities of this type effectively.

The teacher also expresses the need to "stress that they have to refer to a legal regulation or to follow it, because it simulates a real design". (Interview_teacher)

In this way, the simulation comes as close as possible to a real professional engineering project . The intention is that students, in a collaborative way, develop their competences in a simulated project in which the procedures, calculations and functional structures of professional practice are represented.

Several students suggest introducing contrasting elements in the projects for each group, to avoid unnecessary redundancies. On the other hand, these divergences would provide an opportunity for other groups to observe and learn from each other's projects.

Perhaps setting more differences between each group, because the calculations are almost the same for everyone. Then do it a little different. (Interview_student3)

To this end, intergroup collaboration strategies, embodied in the wiki or forum, would enable a fluid exchange with dialogical possibilities. In relation to that, some students point out the need to dedicate more time to clarify the expected purpose of their use and to explain the formative possibilities of these tools.

I think it should be explained better, because they said it in passing... but I also didn't know very well whether it was the teacher who was going to response or whether it was to expose the work to the other students... (Interview_student1) 
Finally, one relevant contribution linked to the need to articulate formative moments of collaboration that favour discussion and joint analysis needs to be highlighted. To this end, one student suggests substituting the final exposition with a session destined for group debate.

Having a discussion instead of a presentation because they were so similar. I felt very much that we were saying the same thing three times in a row. They were small differences, so I do not know if having a discussion and talking about it more like in a collaborative way instead of a presentation just talking about it... (Interview_student5)

This suggestion connects with a training practice commonly developed in the medical field, which can serve as inspiration for experiential engineering training. It is a debriefing (guided discussion) that takes place after a clinical simulation experience (Auerbach et al., 2018). Its aim is ultimately to make explicit those assumptions and mental models that direct and determine professional action. Hence, these professionals can generate self-awareness about what they do and self-correct and optimize their skills and practices.

In conclusion, some guiding principles and suggestions are offered that may help other institutions to integrate PjBL into their educational curricula:

- Think about the curriculum as a whole but start small -start with a small project before reforming a whole subject, a sequence of subjects or the entire degree program-.

- Consider the processes for curriculum change at your university. Plan it because this usually takes much longer than you might expect.

- Immerse students in real projects as much as possible -even looking into the legal implications-. If possible, use real industry partners.

- Give groups different things to do or variations that are significantly different, so that everyone has some novel aspect to grapple with. This avoids groups simply copying from each other.

- Make sure that students have project management tools to ensure that their collaborative work is productive, such as project plans, learning contracts, portfolios, blogs, forum, etc.

- Use debates instead of presentations. You could also get your industry partners in as part of the panel. Students love to have industry people to assess their work and give 'real world' feedback. 


\section{Conclusions}

The aim of the paper is to offer a detailed analysis of an educational proposal based on a PJBL strategy implemented in the Civil Engineering Degree at the University of Cantabria (Spain). This project promotes formative actions of an experiential nature where the student is placed at the centre of the teaching-learning processes. This contrasts with the predominantly used traditional teaching methods in higher education nowadays in Spain. The implementation and analysis of the experience proposed has provided some key lessons that point towards future improvements. They also open new questions regarding the introduction of PjBL experiences such as the one analyzed:

- The need to outline common practices in professional engineering life that involve some conflict or problem. These situations trigger processes of reflection in students that allow them to link theoretical knowledge with practical knowledge, as well as to promote active involvement in their teaching-learning process. In this respect, it is important to find a good balance between guidance and autonomous work, to avoid situations of paralysis but without compromising independent decision-making. This implies a substantial transformation of the teacher-student roles. The former changes from transmitter to mediator or guide and the latter moves from being a passive receiver to becoming an active member and protagonist.

- The need to develop collaborative work proposals in which students share objectives, responsibilities and dilemmas as this will be indispensable in their professional work as engineers. Therefore, promoting collaborative work, using dialogical practices and discursive procedures as central training elements is fundamental to rethink the current civil engineering curriculum.

- The relevance that practical and theoretical training should complement each other. Their balance should allow students to integrate adequately the knowledge, techniques, abilities and decisions that engineers face in their daily work.

PjBL also reveals the pedagogical value of allowing students to make mistakes, which provide great opportunities for learning.

The greatest obstacles identified by the participants for the development of the experience are related with institutional obstacles, such as the absence of time and space to develop these PjBL initiatives or any innovative action that seeks to coexist and complement the system that is already in place. Therefore, to promote the consolidation of the PjBL approach in the coming years, it is necessary to begin to reformulate the traditional curriculum. The PjBL initiatives must 
be adapted to the needs and requirements of each curriculum in terms of the learning in which it should be located, the academic objectives sought, the relationship with the different types of knowledge and their usefulness in evaluation strategies.

To conclude, this work has the value of implementing and studying in detail one of the groundbreaking initiatives of PjBL in engineering at the University of Cantabria and in Spain. It offers countless possibilities of formulating a new and necessary tradition in what we now understand by university teaching in engineering in our context, even with the limitations of constituting a case study.

\section{ACKNOWLEDGEMENTS}

The experience presented in this paper was financially supported by the IV call for innovation learning at University of Cantabria. Name of the project: "Development of innovation, creativity and teamwork skills of civil engineering students by means of projectbased learning ". The authors are particularly grateful to the students who took part in the activity and completed the questionnaires and interviews.

\section{REFERENCES}

Adriaenssens, S., Pauletti, R. M. O., Stockhusen, K., Gabriele, S., Magrone, P., Varano, V., \& Lochner-Aldinger, I. (2015). A Project-Based Approach to Learning Form Finding of Structural Surfaces. International Journal of Space Structures, 30, 297-305.

Ahern, A., O'Connor, T., McRuairc, G., McNamara, M., \& O'Donnell, D. (2012). Critical thinking in the university curriculum - the impact on engineering education. European Journal of Engineering Education, 37(2), 125-132.

Ambrose, S. (2013). Undergraduate engineering curriculum: The ultimate design challenge. The Bridge: Linking Engineering and Society, 43(2), 16-2.

Beavers, E., Orange, A., \& Kirkwood, D. (2017). Fostering critical and reflective thinking in an authentic learning situation. Journal of Early Childhood Teacher Education, 38(1), 3-18.

Bisquerra, R., \& Sabariego, M. (2004). El proceso de investigación (Parte 1). In R. Bisquerra, Metodología de la Investigación Educativa (pp. 89-125). Madrid: La Muralla.

Boud, D., Keogh, R., \& Walker, D. (2013). Reflection: Turning experience into learning. Abingdon: Routledge. 
British Educational Research Association, BERA. (2003) Ethical guidelines for educational research. Draft for consultation among members. Research intelligence, 82, 2-9.

Brockbank, A., \& McGill, I. (1998). Facilitating reflective learning in higher education. Buckingham: Society for Research into Higher Education \& Open University Press.

Brodie, L. (2007). Reflective writing by distance education students in an engineering problem based learning course. Australasian Journal of Engineering Education, 13(2), 31-40.

Brohn, D. M., \& Cowan, J. (1977). Teaching towards an improved understanding of structural behaviour'. The Structural Engineer, 55(1), 9-17.

Brookfield, S. (1998). Critically Reflective Practice. The Journal of Continuing Education in the Health Professions, 18, 197-205.

Bruno, A., \& Dell'Aversana, G. (2018). Reflective practicum in higher education: the influence of the learning environment on the quality of learning. Assessment \& Evaluation in Higher Education, 43(3), 345-358.

Chandrasekaran, S., Stojcevski, A., Littlefair, G., \& Joordens, M. (2013). Project-oriented designbased learning: aligning students' views with industry needs. International journal of engineering education, 29(5), 1109-1118.

Chinowsky, P., Brown, H., Szajnman, A., \& Realph, A. (2006). Developing knowledge landscapes through project-based learning. Journal of professional issues in engineering education and practice, 132(2), 118-124.

Christie, M., \& de Graaff, E. (2017). The philosophical and pedagogical underpinnings of Active Learning in Engineering Education. European Journal of Engineering Education, 42(1), 5-16.

Cosgrove, T., \& O'Reilly, J. (2019). Theory, practice and reflexivity: the next challenge for CDIO? In J. Bennedsen et al. (Eds.), The 15th International CDIO Conference (pp. 867-880). Denmark: AU Library Scholarly Publishing Services.

Cosgrove, T., Phillips, D., \& Quilligan, M. (2010). Educating engineers as if they were human: PBL in civil engineering at the University of Limerick. In 3rd International Symposium for Engineering Education. University College Cork: Ireland.

Cosgrove, T., Ryan, T., \& Slattery, D. M. (2014). Implementing Reflective Writing in a PBL Civil Engineering Programme. In iCEER 2014 McMaster University. Ontario: Hamilton.

De Camargo Ribeiroa, L. R. (2008). Aprendizagem baseada em problemas (PBL) na educação em engenharia. Revista de Ensino de Engenharia, 27(2), 23-32. 
De Graaf, E., \& Kolmos, A. (2003). Characteristics of problem-based learning. International Journal of Engineering Education, 19(5), 657-662.

De los Ríos, Cazorla, A., Díaz-Puente, J. M., \& Yagüe, J. L. (2010). Project-based learning in engineering higher education: two decades of teaching competences in real environments. Procedia - Social and Behavioral Sciences, 2(2), 1368-1378.

Denzin, N. K., \& Lincoln, Y. S. (2013). Manual de investigación cualitativa/The sage handbook of qualitative research. Barcelona: Gedisa.

Du, X., \& Kolmos, A. (2009). Research on PBL practice in engineering education. Rotterdam: Sense Publishers.

Facione, P. (2011). Think critically. Englewood Cliffs, NJ: Pearson.

Fendler, L. (2003). Teacher reflection in a hall of mirrors: Historical influences and political reverberations. Educational researcher, 32(3), 16-25.

Flick, U. (2014). La gestión de la calidad en investigación cualitativa. Madrid: Morata.

Fontana, A., \& Frey, J. H. (2005). The Interview: From Neutral Stance to Political Involvement. In N. K. Denzin \& Y. S. Lincoln (Eds.), The Sage handbook of qualitative research (pp. 695-727). Thousand Oaks, CA: Sage Publications Ltd.

Gavin, K. (2011). Case study of a project-based learning course in civil engineering design. European Journal of Engineering Education, 36(6), 547-558.

Gavin, K. (2012). Use of project based learning to teach geotechnical design skills to civil engineering students. In The international conference: Shaking the Foundations of Geoengineering Education. Galway: CRC PRess.

García-Martín, J., \& Pérez-Martínez, J. E. (2017). Method to guide the design of project based learning activities based on educational theories. International Journal of Engineering Education, 33(3), 984-999.

Greenwood, D. J., \& Levin, M. (2007). Introduction to action research: social research for social change. Thousand Oaks, CA: Sage Publications.

Goetz, J. P., \& LeCompte, M.D. (1988). Etnografía y diseño cualitativo en investigación educativa. Madrid: Morata.

Graeber, A. (2012). Practical PBL Series: Design An Instructional Unit In Seven Phases. Retrieved from: https://www.edutopia.org/blog/practical-pbl-design-amber-graeber 
Graham, R., \& Crawley, E. (2010). Making projects work: a review of transferable best practice approaches to engineering project-based learning in the UK. Engineering education, 5(2), 41-49. Gratchev, I., \& Jeng, D. S. (2018). Introducing a project-based assignment in a traditionally taught engineering course. European Journal of Engineering Education, 43(5), 788-799.

Grinyer, A. (2009). The anonymity of research participants: Assumptions, ethics, and practicalities. Pan-Pacific management review, 12(1), 49-58.

Guerra, A., Ulseth, R., \& Kolmos, A. (2017). PBL in Engineering Education: International Perspectives on Curriculum Change. Rotterdam: Springer.

Heitmann, G. (1996). Project-oriented study and project-organized curricula: A brief review of intentions and solutions. European Journal of Engineering Education, 21(2), 121-131.

Hosseinzadeh, N., \& Hesamzadeh, M. R. (2012). Application of project-based learning (PJBL) to the teaching of electrical power systems engineering. IEEE Transactions on Education, 55(4), 495-501.

Huber, G. L. (2003). Introducción al análisis cualitativo de datos. In A. Medina y S. Castillo (Eds.), Metodología para la realización de Proyectos de Investigación y Tesis Doctorales (pp. 81-129). Madrid: Universitas.

Illeris, K. (1976). Problemorientering og deltagerstyring: oplæg til en alternativ didaktik (Problem Orientation and Participation: Draft for an Alternative Didactic). Munksgaard: Copenhagen.

Jonassen, D. H. (1997). Instructional design models for well-structured and III-structured problem-solving learning outcomes. Educational technology research and development, 45(1), 65-94.

Justo, E., \& Delgado, A. (2015). Change to Competence-Based Education in Structural Engineering. Journal of Professional Issues in Engineering Education and Practice, 141, 1-8.

Kokotsaki, D., Menzies, V., \& Wiggins, A. (2016). Project-based learning: A review of the literature. Improving schools, 19(3), 267-277.

Kolb, D. A. (1984). Experiential learning: Experience as the source of learning and development. New Jersey: Prentice-Hall.

Kolmos, A., \& Rasmussen, P. (1994). De studerendes holdning til kvaliteten ved den teknisknaturvidenskabelige basisuddannelse (The Engineering \& Science Basis Project: The Students' Opinion on the Quality of the Engineering and Science Basic Education Program). Aalborg University: Publication series. 
Kolmos, A. (1996). Reflections on project work and problem-based learning. European journal of engineering education, 21(2), 141-148.

Kuckartz, U. (2007). Realizing Mixed-Methods Approaches with MAXQDA. Documento inédito. Retrieved from: http://www.maxqda.com/download/MixMethMAXQDA-Nov01-2010.pdf

Kvale, S. (2011). Las entrevistas en investigación cualitativa. Madrid: Morata.

Lang, J.D., Cruise, S., McVey, F.D., \& McMasters, J. (1999). Industry expectations of new engineers: A survey to assist curriculum designers. Journal of Engineering Education, 88(1), 4351.

Lantada, A. D., Morgado, P. L., Muñoz-Guijosa, J. M., Sanz, J. L. M., Varri Otero, J. E., García, J. M., ... \& De La Guerra Ochoa, E. (2013). Towards successful project-based teaching-learning experiences in engineering education. International Journal of Engineering Education, 29(2), 476-490.

Larson, J. S., Farnsworth, K., Folkestad, L. S., Tirkolaei, H. K., Glazewski, K., \& Savenye, W. (2018). Using Problem-Based Learning to Enable Application of Foundation Engineering Knowledge in a Real-World Problem. In 2018 IEEE International Conference on Teaching, Assessment, and Learning for Engineering (TALE) (pp. 500-506). IEEE.

Loughran, J. (2002). Effective reflective practice: in search of meaning in learning about teaching. Journal of teacher education, 53(1), 33-43.

Macedo, J., \& Pinho-Lopes, M. (2018). Using Different and Complementary Teaching Tools in Project-Based Learning Application to Civil Engineering-courses on Soil Mechanics. In 3rd International Conference of the Portuguese Society for Engineering Education (CISPEE) (pp. 1-6). Macías, J., San-Segundo, R., Montero, J. M., Ferreiros, J., \& Córdoba, R. (2005). Tools and strategies for improving PBL laboratory courses with a high student-to-Faculty ratio. In Proceedings Frontiers in Education 35th Annual Conference (pp. F2C-7). IEEE.

McCrum, D. (2017). Evaluation of creative problem-solving abilities in undergraduate structural engineers through interdisciplinary problem-based learning. European Journal of Engineering Education, 42(6), 684-700.

McKenna, T., Gibney, A., \& Richardson, M. G. (2018). Benefits and limitations of adopting project-based learning (PJBL) in civil engineering education-a review. IV International Conference on Civil Engineering Education (EUCEET 2018). 
Mills, J. E., \& Treagust, D. F. (2003). Engineering education-Is problem-based or project-based learning the answer. Australasian journal of engineering education, 3(2), 2-16.

Miranda, M., Da Costa, A., Castro, J., \& Saiz, Á. (2019). A case study of a project based learning activity implemented in a geotechnical engineering course. In 11th International Conference on Education and New Learning Technologies.

Moon, J. (2007). Getting the measure of reflection: considering matters of definition and depth. Journal of Radiotherapy in Practice, 6(4), 191-200.

Nelson, L. M. (1999). Collaborative problem solving. Instructional design theories and models: A new paradigm of instructional theory, 2, 241-267.

Nordstrom, K., \& Korpelainen, P. (2011). Creativity and inspiration for problem solving in engineering education. Teaching in Higher Education, 16(4), 439-450.

Peréz-Gomar, G. (2016). La matriz insonora del cambio educativo: la organización escolar. Perspectivas para su investigación. REXE-Revista de Estudios y Experiencias en Educación, 7(13), $43-60$.

Pérez, L., Fernández, R., \& Franco, A. (2011). Multidisciplinary education for new landscape engineering concepts using problem-based collaborative learning. A case study in spain. International Journal of Engineering Education, 27(1), 138-145.

Perrenet, J. C., Bouhuijs, P. A. J., \& Smits, J. G. M. M. (2000). The suitability of problem-based learning for engineering education: theory and practice. Teaching in higher education, 5(3), 345358.

Pinho-Lopes, M., \& Macedo, J. (2016). Project-based learning in Geotechnics: cooperative versus collaborative teamwork. European Journal of Engineering Education, 41(1), 70-90.

Rapley, T. (2014). Los análisis de conversación, de discurso y de documentos en investigación cualitativa. Ediciones Morata.

Russell, T. (2018). A teacher educator's lessons learned from reflective practice. European Journal of Teacher Education, 41(1), 4-14.

Schön, D. (1983). The reflective practitioner: how professionals think in action. New York: Basic Books.

Schön, D. (1987). Educating the reflective practitioner. San Francisco London: Jossey-Bass.

Schmidt, H. G. (1983). Problem-based Learning: Rationale and Description. Medical Education, $17,11-16$ 
Silva, F. B., Sabbatini, F. H., \& de Barros, M. M. (2012). Project-Based Learning in Civil Engineering Education: an Experience at the University of São Paulo. In International Symposium on Project Approaches in Engieering Education, Sao Paulo.

Simons, H. (2011). El estudio de caso: Teoría y práctica. Ediciones Morata.

Sonntag, M. (2006). Reflexive pedagogy in the apprenticeship in design. European Journal of Engineering Education, 31(1), 109-117.

Starcher, R. D., \& Pierce, C. E. (2016). Problem-Based Learning with EFFECTs: Part II-Ground Improvement Module for Lab Courses. In International Conference on Geo-Engineering Education Shaping the Future of Geotechnical Education. .

Thomas, J. W. (2000). A review of research on project-based learning. Retrieved from: http://www.bobpearlman.org/BestPractices/PBL_Research.pdf

Thompson, N., \& Pascal, J. (2012). Developing critically reflective practice. Reflective practice, $13(2), 311-325$.

Turns, J. A., Sattler, B., Yasuhara, K., Borgford-Parnell, J., \& Atman, C. J. (2014). Integrating reflection into engineering education. In 121st ASEE Annual Conference \& Exposition.

Wolfs, P. J., Howard, P., Vann, A., \& Boyd, P. (1998). Experiences with the first year of a project based engineering degree. In Waves of Change: Proceedings of the 10th Australasian Conference on Engineering Education, 5th Australasian Women in Engineering Forum, 5th National Conference on Teaching Engineering Designers (p. 59). Central Queensland University: James Goldston Faculty of Engineering and Physical Systems.

Wong, A. C. K. (2016). Considering reflection from the student perspective in higher education. Sage Open, 6(1).

Yadav, A., Subedi, D., Lundeberg, M. A., \& Bunting, C. F. (2011). Problem-based learning: Influence on students' learning in an electrical engineering course. Journal of Engineering Education, 100(2), 253-280.

Zeichner, K. (2010). New epistemologies in teacher education. Rethinking the connections between campus courses and practical experiences in Teacher. Education at university. Journal of teacher education, 61, 89-99. 